Petr Budinský, Ph.D, Associate Professor of Department of Finance, Faculty of Economic Studies, University of Finance and Administration (Prague, Czech Republic);

Michal Bezvoda

Ing, Department of Finance, Faculty of Economic Studies, University of Finance and Administration (Prague, Czech Republic)

\title{
INNOVATIVE APPROACH TO THE MANAGEMENT OF CREDIT RISK ${ }^{1}$
}

Credit rating is a traditional measurement of credit risk in financial markets. This paper introduces an innovative approach based on implied ratings defined by CDS spreads. Using this approach the credit risk can be better managed because CDS are provided on daily basis. The implied rating is compared with credit ratings provided by Moody's, S\&P, and Fitch. The model of implied rating deals only with sovereign ratings. 52 countries were chosen for comparison of both types of above-mentioned ratings. The model uses cumulative default probabilities (CPD) derived from CDS spreads and the main results are CPD intervals which define implied credit ratings. For those countries where the credit rating and implied credit rating are different, the paper shows how implied rating can serve as a signal for potential upgrade or downgrade of the credit rating provided by rating agencies. The presented model is also used to verify ratings provided by Moody's, S\&P, and Fitch in cases where these agencies provide different ratings for a specific country. This is especially important when some ratings are investment-grade and others are speculative-grade.

Keywords: credit rating, credit risk management, rating agency, credit default swap (CDS), cumulative probability of default (CPD).

DOI: 10.21272/mmi.2018.1-25

Introduction. Credit rating agencies provide credit ratings for issuers of debt instruments. Issuers are governments, companies, or municipalities. The credit rating is based on the issuer's ability to repay debt and reflects its creditworthiness. The higher the credit rating, the lower the probability of default. The most respected credit rating agencies are Standard and Poor's (S\&P) [15], Moody's [14], and Fitch [16]. They classify issuers into several credit rating categories. The following categories are investment-grade ratings (Table 1):

Table 1 - Long-term Credit Ratings - Investment Grade (built by authors based on [14-16])

\begin{tabular}{|c|c|c|}
\hline Moody's & S\&P & Fitch \\
\hline Aaa & AAA & AAA \\
\hline Aa1 & AA+ + \\
\hline Aa2 & AA & AA \\
\hline Aa3 & AA- & A - \\
\hline A1 & A+ & A \\
\hline A2 & A & A- \\
\hline A3 & A- & BBB+ \\
\hline Baa1 & BBB+ & BBB \\
\hline Baa2 & BBB & BBB- \\
\hline
\end{tabular}

The highest rating is $A A A$ and the probability of default in this case is very low. In this paper, four rating categories are used: $A A A, A A, A$ and $B B B$. Moody's ratings $A 1, A 2$ and $A 3$ are considered as being category $A$, and S\&P/Fitch ratings BBB+, BBB and BBB- are considered as BBB. The categories in Table 2 express speculative-grade ratings.

Here the probability of default is substantially higher than for investment-grade issuers. We will use

\footnotetext{
1 The paper has been prepared under the project "New Sources of Systemic Risk in the Financial Markets", supported by the Czech Science Foundation (No. 16-21506S, 2016-2018)
} 


\section{П. Будінській, М. Безвода. Інноваційний підхід до управління кредитним ризиком}

the "S" category to represent all the speculative-grade ratings in Table 2. This paper deals only with sovereign ratings to 31 January, 2017, where 52 countries were selected and categorized within the categories introduced above: AAA (9 countries), AA (10 countries), A (11 countries), BBB (13 countries), and $S$ ( 9 countries), all based upon their median rating among the three above-mentioned rating agencies.

Table 2 - Long-term Credit Ratings - Speculative Grade (built by authors based on [14-16])

\begin{tabular}{|c|c|c|}
\hline Moody's & S\&P & Fitch \\
\hline Ba1 & BB+ & BB+ \\
\hline Ba2 & BB & BB- \\
\hline Ba3 & BB- & B+ \\
\hline B1 & B+ & B \\
\hline B2 & B & CCC+ \\
\hline B3 & B- & CCC \\
\hline Caa1 & CCC+ CCC- \\
\hline Caa2 & CCC & CC \\
\hline Caa3 & CCC- & CC \\
\hline Ca & & C \\
\hline
\end{tabular}

A feature of credit ratings is that they do not change frequently. In one respect, this brings stability, but it does not allow them to be adjusted due to actual events as rapidly as necessary. The main objective of this paper is to introduce a different type of rating based on market instruments that will allow investors to analyze the status of issuers on a daily basis. The selected market instrument is the credit default swap (CDS) which will aid in defining the implied rating. A CDS is a œntract where a bond is the underlying asset and the CDS functions as insurance in case the bond defaults. The riskier the underlying bond, the higher the CDS price (also called "CDS spread") will be, and so therefore the higher the probability of default. Defaulting means that some or all payments associated with the bond will not be recovered by the investor. The CDS seller is obliged to deliver missing payments to the CDS buyer. Based on the CDS spread, the cumulative probability of default (CPD) can be calculated. The CPD is the probability that the bond will default before expiration of the relevant CDS (normally 5 years). We have defined the implied rating for 52 selected countries based on their CPD.

The research methodology. CDSs offer the market an additional tool to determine the degree of credit risk. Unlike agency ratings, which are discrete and are only adjusted after time, usually in response to an important event related to underlying assets, CDS prices change in real time. The market reacts to events much faster than the time it takes for agencies to change their ratings.

Georgievska et al. [10] estimated default probabilities of emerging countries and compared them with the default rates implied by sovereign credit ratings. They detected that CRAs generally underestimated the risk of sovereign debt, and that sovereign credit ratings from rating agencies were much too optimistic.

Callen et al. [5] observed that credit ratings may have a close relationship with CDS spreads with respect to obligors sharing a common credit rating. They found that earnings of referenced firms are negatively correlated with the level of CDS prices, consistent with earnings conveying information about default risk.

In accordance with lyengar [11, 12], we found differences among the sovereign ratings granted by Moody's, Standard \& Poor's, and Fitch. He carried out a comparison of sovereign ratings and examined their differences. Results showed that these differences are statistically significant and that they increase over time. This may lead to increased doubts about the consistency of such ratings.

De Haan [8] provided a basic background on the functioning of rating agencies. He focused on two main tasks for which rating agencies have come under criticism, namely the rating of structured instruments, and the issuing of sovereign ratings. Based on these tasks, they investigated how and whether there should be regulation. 
Budinsky et al. 2] focused on the theory of equality between CDS spreads and bond spreads. This theory was valid for selected European countries before Lehman Brothers, but after October 2008, it was valid for these countries only in some time periods.

Cizel [7] argued that CDS spreads are a market-based measurement of credit risk relative to credit risk ratings. If CDS spreads represent an element of pure credit risk, and credit ratings are a relative default risk metric, then there should be a connection between the market price of credit risk and the credit rating assigned to an obligor.

Castellano and D'Ecclesia [6] investigated the ability of fluctuations in CDS indexes in anticipating the occurrence of market crises. They found that CDS volatility tends to increase almost eight months before the market changes, confirming the impressive informational value of CDS changes that may reflect future expectations.

Budinský [3]researched that implied rating based on CPD could be used to check sovereign ratings obtained by rating agencies through implied rating categories.

Kiesel [13] analyzed the impact and effectiveness of regulation on the European sovereign CDS market. He focused on regulation that prohibits buying uncovered sovereign CDS contracts in the European Union. His results indicated significant change in CDS spreads prior to regulations and stable CDS spreads following the introduction of regulation.

Berg [1] was focused on monitoring 57 countries and he found that the CDS market relative to a country's debt is substantially larger for small countries, countries just above investment-grade, and countries with weaker creditor rights. Further, he came to view that the CDS market usually reacts only to negative events, and that changes in the size of CDS markets are determined by agency ratings.

Budinský et al. [4] suggested two methods to measure credit risk. He investigated bond and CDS spreads in the equilibrium model and found that changes in economic situations may lead to the change of both bond and CDS spreads.

Drago and Gallo [9] analyzed the impact of sovereign ratings announcements on the CDS market. The study concluded that agency warnings had zero to little impact on the CDS market. Based on his study, the market seems to react only to negative announcements.

Model of implied ratings. Before we introduce the model for implied rating, we must place each selected country into category $\mathrm{AAA}, \mathrm{AA}, \mathrm{A}, \mathrm{BBB}$, or $\mathrm{S}$. The median rating is introduced here based on omitting the best and worst of three different ratings (Moody's, S\&P and Fitch). If at least two ratings are the same, the median rating is defined by those ratings. The median rating categories are in Table 3.

Table 3 - Ratings of Selected Countries by Moody's, S\&P, Fitch and Median Rating (built by authors based on [14-16])

\begin{tabular}{|c|c|c|c|c|c|}
\hline No. & Country & Moody's & S\&P & Fitch & Median Rating \\
\hline 1 & Australia & Aaa & AAA & AAA & AAA \\
\hline 2 & Norway & Aaa & AAA & AAA & AAA \\
\hline 3 & Denmark & Aaa & AAA & AAA & AAA \\
\hline 4 & Germany & Aaa & AAA & AAA & AAA \\
\hline 5 & Sweden & Aaa & AAA & AAA & AAA \\
\hline 6 & Netherlands & Aaa & AA+ & AAA & AAA \\
\hline 7 & United States & Aaa & AAA & AAA & AAA \\
\hline 8 & Canada & Aaa & AAA & AAA & AAA \\
\hline 9 & Singapore & Aa1 & AA+ & AA+ & AA \\
\hline 10 & Finland & Aa1 & AA & AA & AA \\
\hline 11 & United Kingdom & Aa1 & AA+ & AA+ & AA \\
\hline 12 & Austria & Aa3 & AA & AA & AA \\
\hline 13 & Belgium & Aa2 & AA & AA & AA \\
\hline 14 & France & & & & \\
\hline
\end{tabular}




\begin{tabular}{|c|c|c|c|c|c|}
\hline No. & Country & Moody's & S\&P & Fitch & Median Rating \\
\hline 15 & South Korea & $\mathrm{Aa} 2$ & $\mathrm{AA}$ & AA- & $\mathrm{AA}$ \\
\hline 16 & Abu Dhabi & Aa2 & AA & AA- & AA \\
\hline 17 & Qatar & Aa2 & AA & AA- & $\mathrm{AA}$ \\
\hline 18 & Chile & Aa3 & AA- & $A+$ & AA \\
\hline 19 & China & Aa3 & AA- & $\mathrm{A}^{+}$ & AA \\
\hline 20 & Japan & $\mathrm{A} 1$ & $A+$ & $A$ & A \\
\hline 21 & Czech Republic & A1 & AA- & $A+$ & $\mathrm{A}$ \\
\hline 22 & Slovakia & A2 & A & $A+$ & A \\
\hline 23 & Estonia & $\mathrm{A} 1$ & AA- & $A+$ & A \\
\hline 24 & Latvia & A3 & A- & A- & $A$ \\
\hline 25 & Ireland & A3 & $A+$ & A & A \\
\hline 26 & Poland & $\mathrm{A} 2$ & $\mathrm{BBB}+$ & A- & $\mathrm{A}$ \\
\hline 27 & Israel & $\mathrm{A} 1$ & $A+$ & $A$ & $\bar{A}$ \\
\hline 28 & Peru & A3 & $\mathrm{A}+$ & $\bar{A}$ & $A$ \\
\hline 29 & Malaysia & A3 & $A$ & $\mathrm{~A}$ & $A$ \\
\hline 30 & Slovenia & Baa3 & A & A- & A \\
\hline 31 & Spain & Baa2 & $\mathrm{BBB}+$ & BBB+ & BBB \\
\hline 32 & Thailand & Baa1 & BBB+ & BBB+ & BBB \\
\hline 33 & Philippines & Baa2 & BBB & BBB+ & BBB \\
\hline 34 & Romania & Baa3 & BBB- & BBB- & BBB \\
\hline 35 & Panama & Baa2 & BBB+ & BBB & BBB \\
\hline 36 & Mexico & A3 & $\mathrm{BBB}+$ & $\mathrm{BBB}+$ & BBB \\
\hline 37 & Italy & Baa2 & BBB- & BBB+ & BBB \\
\hline 38 & Kazakhstan & Baa3 & BBB+ & BBB & BBB \\
\hline 39 & Colombia & Baa2 & BBB- & BBB+ & BBB \\
\hline 40 & South Africa & Baa2 & BBB- & BBB- & BBB \\
\hline 41 & Hungary & Baa3 & $\mathrm{BB}+$ & BBB- & BBB \\
\hline 42 & Bulgaria & Baa2 & $\mathrm{BB}+$ & BBB- & BBB \\
\hline 43 & Indonesia & Baa3 & $\mathrm{BB}+$ & BBB- & BBB \\
\hline 44 & Russia & Ba1 & $\mathrm{BB}+$ & BBB- & $\mathrm{S}$ \\
\hline 45 & Turkey & Ba1 & $\mathrm{BB}+$ & BBB- & $S$ \\
\hline 46 & Vietnam & $\mathrm{B} 1$ & BB- & BB & $S$ \\
\hline 47 & Croatia & $\mathrm{Ba} 2$ & BB & $\mathrm{BB}$ & $S$ \\
\hline 48 & Brazil & $\mathrm{Ba} 2$ & BB & BB & S \\
\hline 49 & Portugal & Ba1 & $\mathrm{BB}+$ & $\mathrm{BB}+$ & $S$ \\
\hline 50 & Argentina & B3 & B- & $B$ & S \\
\hline 51 & Egypt & B3 & B- & $\mathrm{B}$ & $S$ \\
\hline 52 & Venezuela & Caa3 & $\mathrm{CCC}$ & $\mathrm{CCC}$ & $S$ \\
\hline
\end{tabular}

Table 3 shows that all three rating agencies placed 38 countries into the same rating category and that only 14 countries (the Netherlands, the United States, Chile, China, the Czech Republic, Estonia, Poland, Slovenia, Mexico, Hungary, Bulgaria, Indonesia, Russia, Turkey) have differing rating categories from two separate rating agencies. None of the countries have three different rating categories, so the ratings are very similar.

The model of using CDS spreads and CPD (cumulative probabilities of default) is based on the following idea: the better the credit rating, the lower the CDS spread [2], and the lower the CPD [3]. Table 4 has been compiled based on this. We do not use mathematical calculation of CPD based on CDS spreads because we used data directly from Deutsche Bank Research (31 January, 2017).

Table 4-CDS and CPD for Selected Countries (compiled by the authors based on [17])

\begin{tabular}{|c|c|c|c|}
\hline No. & Country & 5 Year CPD (\%) & 5 Year CDS Spread (bps) \\
\hline 1 & United States & $1,19 \%$ & 28 \\
\hline 2 & Germany & $1,39 \%$ & 25 \\
\hline 3 & Australia & $1,49 \%$ & 21 \\
\hline 4 & Sweden & $1,54 \%$ & 25 \\
\hline 5 & Finland & $1,89 \%$ & 25 \\
\hline
\end{tabular}


Continuation of Table 4

\begin{tabular}{|c|c|c|c|}
\hline No. & Country & 5 Year CPD (\%) & 5 Year CDS Spread (bps) \\
\hline 6 & Norway & $1,93 \%$ & 23 \\
\hline 7 & Austria & $1,98 \%$ & 34 \\
\hline 8 & Denmark & $2,03 \%$ & 24 \\
\hline 9 & United Kingdom & $2,03 \%$ & 33 \\
\hline 10 & Canada & $2,08 \%$ & 33 \\
\hline 11 & Netherlands & $2,33 \%$ & 28 \\
\hline 12 & Japan & $2,33 \%$ & 33 \\
\hline 13 & Belgium & $2,48 \%$ & 36 \\
\hline 14 & France & $3,06 \%$ & 39 \\
\hline 15 & Slovakia & $3,16 \%$ & 47 \\
\hline 16 & Czech Republic & $3,69 \%$ & 43 \\
\hline 17 & South Korea & $4,08 \%$ & 46 \\
\hline 18 & Estonia & $4,52 \%$ & 57 \\
\hline 19 & Abu Dhabi & $4,71 \%$ & 62 \\
\hline 20 & Singapore & $4,85 \%$ & 60 \\
\hline 21 & Latvia & $5,00 \%$ & 63 \\
\hline 22 & Ireland & $5,04 \%$ & 64 \\
\hline 23 & Spain & $5,95 \%$ & 78 \\
\hline 24 & Israel & $6,10 \%$ & 77 \\
\hline 25 & Qatar & $6,24 \%$ & 80 \\
\hline 26 & Thailand & $6,33 \%$ & 81 \\
\hline 27 & Poland & $6,43 \%$ & 76 \\
\hline 28 & Chile & $7,14 \%$ & 83 \\
\hline 29 & Philippines & $7,37 \%$ & 99 \\
\hline 30 & Slovenia & $8,22 \%$ & 103 \\
\hline 31 & Romania & $8,40 \%$ & 108 \\
\hline 32 & Peru & $8,45 \%$ & 108 \\
\hline 33 & China & $8,64 \%$ & 117 \\
\hline 34 & Hungary & $8,87 \%$ & 123 \\
\hline 35 & Bulgaria & $9,15 \%$ & 143 \\
\hline 36 & Malaysia & $10,11 \%$ & 134 \\
\hline 37 & Panama & $10,30 \%$ & 129 \\
\hline 38 & Indonesia & $11,39 \%$ & 154 \\
\hline 39 & Italy & $11,80 \%$ & 157 \\
\hline 40 & Colombia & $11,94 \%$ & 161 \\
\hline 41 & Kazakhstan & $11,98 \%$ & 157 \\
\hline 42 & Mexico & $12,25 \%$ & 154 \\
\hline 43 & Russia & $12,97 \%$ & 176 \\
\hline 44 & Vietnam & $14,17 \%$ & 189 \\
\hline 45 & South Africa & $15,23 \%$ & 211 \\
\hline 46 & Croatia & $15,62 \%$ & 210 \\
\hline 47 & Brazil & $17,61 \%$ & 273 \\
\hline 48 & Turkey & $18,59 \%$ & 269 \\
\hline 49 & Portugal & $18,84 \%$ & 274 \\
\hline 50 & Egypt & $27,04 \%$ & 435 \\
\hline 51 & Argentina & $29,98 \%$ & 432 \\
\hline 52 & Venezuela & $65,67 \%$ & 3193 \\
\hline
\end{tabular}

The cumulative probability of default within five years is lower than $2 \%$ for seven countries (the United States, Germany, Australia, Sweden, Finland, Norway and Austria), so their implied rating category of AAA is expected. On the other hand, three countries with CPD higher than $25 \%$ would dearly be in the $S$ category. We now derive the exact model, which allows us b put each country into its respective implied rating category. This is done based on Table 5, which combines the ratings from Table 3 with CPD from Table 4. The countries in Table 5 are in sequence by their CPD - from the lowest to the highest. The sequences of countries in Table 3 and Table 4 are similar. 
П. Будінській, М. Безвода. Інноваційний підхід до управління кредитним ризиком

Table 5- CPD and Median Rating (compiled by the author)

\begin{tabular}{|c|c|c|c|}
\hline No. & Country & 5 Year CPD (\%) & Median Rating \\
\hline 1 & United States & $1,19 \%$ & AAA \\
\hline 2 & Germany & $1,39 \%$ & AAA \\
\hline 3 & Australia & $1,49 \%$ & AAA \\
\hline 4 & Sweden & $1,54 \%$ & AAA \\
\hline 5 & Finland & $1,89 \%$ & $\mathrm{AA}$ \\
\hline 6 & Norway & $1,93 \%$ & AAA \\
\hline 7 & Austria & $1,98 \%$ & $\mathrm{AA}$ \\
\hline 8 & Denmark & $2,03 \%$ & AAA \\
\hline 9 & United Kingdom & $2,03 \%$ & $\mathrm{AA}$ \\
\hline 10 & Canada & $2,08 \%$ & AAA \\
\hline 11 & Netherlands & $2,33 \%$ & AAA \\
\hline 12 & Japan & $2,33 \%$ & $\mathrm{~A}$ \\
\hline 13 & Belgium & $2,48 \%$ & AA \\
\hline 14 & France & $3,06 \%$ & AA \\
\hline 15 & Slovakia & $3,16 \%$ & $A$ \\
\hline 16 & Czech Republic & $3,69 \%$ & $\mathrm{~A}$ \\
\hline 17 & South Korea & $4,08 \%$ & AA \\
\hline 18 & Estonia & $4,52 \%$ & $A$ \\
\hline 19 & Abu Dhabi & $4,71 \%$ & AA \\
\hline 20 & Singapore & $4,85 \%$ & AAA \\
\hline 21 & Latvia & $5,00 \%$ & $A$ \\
\hline 22 & Ireland & $5,04 \%$ & $A$ \\
\hline 23 & Spain & $5,95 \%$ & BBB \\
\hline 24 & Israel & $6,10 \%$ & $A$ \\
\hline 25 & Qatar & $6,24 \%$ & $\mathrm{AA}$ \\
\hline 26 & Thailand & $6,33 \%$ & BBB \\
\hline 27 & Poland & $6,43 \%$ & $A$ \\
\hline 28 & Chile & $7,14 \%$ & $\mathrm{AA}$ \\
\hline 29 & Philippines & $7,37 \%$ & BBB \\
\hline 30 & Slovenia & $8,22 \%$ & $A$ \\
\hline 31 & Romania & $8,40 \%$ & BBB \\
\hline 32 & Peru & $8,45 \%$ & $A$ \\
\hline 33 & China & $8,64 \%$ & $\mathrm{AA}$ \\
\hline 34 & Hungary & $8,87 \%$ & BBB \\
\hline 35 & Bulgaria & $9,15 \%$ & BBB \\
\hline 36 & Malaysia & $10,11 \%$ & $\mathrm{~A}$ \\
\hline 37 & Panama & $10,30 \%$ & BBB \\
\hline 38 & Indonesia & $11,39 \%$ & BBB \\
\hline 39 & Italy & $11,80 \%$ & BBB \\
\hline 40 & Colombia & $11,94 \%$ & BBB \\
\hline 41 & Kazakhstan & $11,98 \%$ & BBB \\
\hline 42 & Mexico & $12,25 \%$ & BBB \\
\hline 43 & Russia & $12,97 \%$ & $S$ \\
\hline 44 & Vietnam & $14,17 \%$ & $\mathrm{~S}$ \\
\hline 45 & South Africa & $15,23 \%$ & BBB \\
\hline 46 & Croatia & $15,62 \%$ & $S$ \\
\hline 47 & Brazil & $17,61 \%$ & $S$ \\
\hline 48 & Turkey & $18,59 \%$ & $S$ \\
\hline 49 & Portugal & $18,84 \%$ & $S$ \\
\hline 50 & Egypt & $27,04 \%$ & $S$ \\
\hline 51 & Argentina & $29,98 \%$ & $\mathrm{~S}$ \\
\hline 52 & Venezuela & $65,67 \%$ & $S$ \\
\hline
\end{tabular}


We can see that Finland, Austria and the United Kingdom (in the AA category) are distributed among the AAA category countries. Peru, China, and Malaysia, which are in the A and AA categories, are distributed among the BBB category countries. We must determine CPD ranges to maximize the number of countries with matching rating categories and implied ratings (see Table 6).

Table 6 - Implied Rating Categories (compiled by the authors)

\begin{tabular}{|c|c|}
\hline 5 Year CPD (\%) & Implied Rating \\
\hline $0-2,09$ & AAA \\
\hline $2,10-4,19$ & AA \\
\hline $4,20-6,29$ & A \\
\hline $6,30-12,59$ & BBB \\
\hline$>12,60$ & S \\
\hline
\end{tabular}

The choice of ranges defining the intervals for CPD is not unique. Instead of 2,10, we could use 2,20 or 2,30 with the same result, or instead of 4,20, we could use 4,30 or 4,40. The solution represented in Table 6 is important because the ranges of intervals for the implied ratings $A A A, A A$, and $A$ are 2,10 , and the range of the fourth interval (BBB) is 6,30, which $3 \times 2,10$.

Presentation of results. The above introduced model will now be applied to the selected 52 countries. Using Table 3 for rating categories AAA, AA, A, BBB and S, we created the following tables: Table 7 for the AAA category, Table 8 for the AA category, Table 9 for the A category, Table 10 for the BBB category, and Table 11 for the $\mathrm{S}$ category. These tables list implied rating categories based on the CPD intervals from Table 6.

Table 7 - Countries with AAA Median rating (compiled by the authors)

\begin{tabular}{|c|c|c|c|c|c|}
\hline Country & Moody's & S\&P & Fitch & Median Rating & Implied Rating \\
\hline Australia & Aaa & AAA & AAA & AAA & AAA \\
\hline Norway & Aaa & AAA & AAA & AAA & AAA \\
\hline Denmark & Aaa & AAA & AAA & AAA & AAA \\
\hline Germany & Aaa & AAA & AAA & AAA & AAA \\
\hline Sweden & Aaa & AAA & AAA & AAA & AA \\
\hline Netherlands & Aaa & AA+ & AAA & AAA & AAA \\
\hline United States & Aaa & AA+ & AAA & AAA & AAA \\
\hline Canada & Aaa & AAA & AAA & AAA & AA \\
\hline Singapore & Aaa & AAA & AAA & & \\
\hline
\end{tabular}

In Table 7 there are only two countries in the AAA median rating category (the Netherlands and Singapore) where the median rating (AAA) differs from the implied rating (AA). Implied rating is in both cases lower than the median rating. For the other seven countries, both ratings are the same (AAA).

Table 8 - Countries with AA Median Rating (compiled by the authors)

\begin{tabular}{|c|c|c|c|c|c|}
\hline Country & Moody's & S\&P & Fitch & Median Rating & Implied Rating \\
\hline Finland & Aa1 & $\mathrm{AA}+$ & $\mathrm{AA}+$ & $\mathrm{AA}$ & AAA \\
\hline United Kingdom & Aa1 & $\mathrm{AA}$ & $\mathrm{AA}$ & AA & AAA \\
\hline Austria & Aa1 & $\mathrm{AA}+$ & $\mathrm{AA}+$ & AA & AAA \\
\hline Belgium & Aa3 & $\mathrm{AA}$ & $\mathrm{AA}$ & $\mathrm{AA}$ & $\mathrm{AA}$ \\
\hline France & Aa2 & AA & $\mathrm{AA}$ & AA & $\mathrm{AA}$ \\
\hline South Korea & Aa2 & AA & AA- & AA & AA \\
\hline Abu Dhabi & Aa2 & AA & AA- & AA & $A$ \\
\hline Qatar & Aa2 & AA & AA- & $\mathrm{AA}$ & A \\
\hline Chile & Aa3 & AA- & $A+$ & AA & BBB \\
\hline China & Aa3 & AA- & $A+$ & $\mathrm{AA}$ & BBB \\
\hline
\end{tabular}


П. Будінській, М. Безвода. Інноваційний підхід до управління кредитним ризиком

There are three countries (Belgium, France and South Korea) in the AA median rating category (Table 8) where the median rating $(A A)$ coincides with the implied rating $(A A)$. For the other seven countries, both ratings are different, whereas the biggest differences are found for Chile and China, with their implied ratings of $\mathrm{BBB}$ being significantly lower than $\mathrm{AA}$.

Table 9 - Countries with A Median Rating (compiled by the authors)

\begin{tabular}{|c|c|c|c|c|c|}
\hline Country & Moody's & S\&P & Fitch & Median Rating & Implied Rating \\
\hline Japan & $\mathrm{A} 1$ & $\mathrm{~A}+$ & $\mathrm{A}$ & $\mathrm{A}$ & $\mathrm{AA}$ \\
\hline Czech Republic & $\mathrm{A} 1$ & $\mathrm{AA}-$ & $\mathrm{A}+$ & $\mathrm{A}$ & $\mathrm{A}$ \\
\hline Slovakia & $\mathrm{A} 2$ & $\mathrm{~A}$ & $\mathrm{~A}+$ & $\mathrm{A}$ & $\mathrm{A}$ \\
\hline Estonia & $\mathrm{A} 1$ & $\mathrm{AA}-$ & $\mathrm{A}+$ & $\mathrm{A}$ & $\mathrm{A}$ \\
\hline Latvia & $\mathrm{A} 3$ & $\mathrm{~A}-$ & $\mathrm{A}-$ & $\mathrm{A}$ & $\mathrm{A}$ \\
\hline Ireland & $\mathrm{A} 3$ & $\mathrm{~A}+$ & $\mathrm{A}$ & $\mathrm{A}$ & $\mathrm{B}$ \\
\hline Poland & $\mathrm{A} 2$ & $\mathrm{BBB}+$ & $\mathrm{A}-$ & $\mathrm{A}$ & $\mathrm{A}$ \\
\hline Israel & $\mathrm{A} 1$ & $\mathrm{~A}+$ & $\mathrm{A}$ & $\mathrm{A}$ & $\mathrm{BBB}$ \\
\hline Peru & $\mathrm{A} 3$ & $\mathrm{~A}+$ & $\mathrm{A}$ & $\mathrm{A}$ & $\mathrm{BBB}$ \\
\hline Malaysia & $\mathrm{A} 3$ & $\mathrm{~A}$ & $\mathrm{~A}$ & $\mathrm{~A}$ & $\mathrm{BBB}$ \\
\hline Slovenia & $\mathrm{Baa} 3$ & $\mathrm{~A}$ & $\mathrm{~A}-$ & & $\mathrm{A}$ \\
\hline
\end{tabular}

In median rating category $A$ (Table 9), there are four countries (Estonia, Latvia, Ireland, and Israel) where the median rating $(A)$ coincides with the implied rating $(A)$. For the other seven countries, both ratings are different.

Table 10 - Countries with BBB Median Rating (compiled by the authors)

\begin{tabular}{|c|c|c|c|c|c|}
\hline Country & Moody's & S\&P & Fitch & Median Rating & Implied Rating \\
\hline Spain & Baa2 & BBB + & BBB + & BBB & A \\
\hline Thailand & Baa1 & BBB + & BBB + & BBB & BBB \\
\hline Philippines & Baa2 & BBB & BBB + & BBB & BBB \\
\hline Romania & Baa3 & BBB- & BBB- & BBB & BBB \\
\hline Hungary & Baa3 & BB+ & BBB- & BBB & BBB \\
\hline Panama & Baa2 & BBB + & BBB & BBB & BBB \\
\hline Bulgaria & Baa2 & BB + & BBB- & BBB & BBB \\
\hline Mexic0 & A3 & BBB + & BBB + & BBB & BBB \\
\hline Indonesia & Baa3 & BB+ & BBB- & BBB & BBB \\
\hline Italy & Baa2 & BBB- & BBB + & BBB & BBB \\
\hline Kazakhstan & Baa3 & BBB + & BBB & BBB & BBB \\
\hline Colombia & Baa2 & BBB- & BBB + & BBB & BBB \\
\hline South Africa & Baa2 & BBB- & BBB- & BBB & S \\
\hline
\end{tabular}

In median rating category BBB (Table 10), there are only two countries (Spain and South Africa) where the median rating (BBB) is different from the implied rating (A for Spain and S for South Africa). For the other 11 countries, both ratings are the same (BBB), but the S\&P credit ratings for Hungary, Bulgaria and Indonesia are $\mathrm{BB}+$ (S category).

Nine countries are in median rating category $S$ (Table 11). The median rating (S) coincides with the implied rating $(S)$ for all of these countries, but the Fitch credit ratings for Russia and Turkey are BBB(BBB category).

Summarizing the content of the previous section, we can conclude that the median rating and implied rating are the same for 34 countries, and different for 18 countries. We can divide these 18 countries into 3 groups:

- Median rating lower than implied rating - seven œuntries (Table 12)

- Median rating slightly higher than implied rating- seven countries (Table 13)

- Median rating significantly higher than implied rating- four countries (Table 14) 
Table 11 - Countries with S Median Rating (compiled by the authors)

\begin{tabular}{|c|c|c|c|c|c|}
\hline Country & Moody's & S\&P & Fitch & Median Rating & Implied Rating \\
\hline Russia & Ba1 & BB+ & BBB- & S & S \\
\hline Vietnam & B1 & BB- & BB & S & S \\
\hline Croatia & Ba2 & BB & BB & S & S \\
\hline Turkey & Ba1 & BB+ & BBB- & S & S \\
\hline Brazil & Ba2 & BB & BB & S & S \\
\hline Portugal & Ba1 & BB+ & BB+ & S & S \\
\hline Argentina & B3 & B- & B & S & S \\
\hline Russia & Ba1 & BB+ & BBB- & S & S \\
\hline Venezuela & Caa3 & CCC & CCC & S & S \\
\hline
\end{tabular}

Table 12 - Countries with Lower Median Rating than Implied Rating (compiled by the authors)

\begin{tabular}{|c|c|c|}
\hline Country & Median Rating & Implied Rating \\
\hline Finland & AA & AAA \\
\hline United Kingdom & AA & AAA \\
\hline Austria & AA & AA \\
\hline Czech Republic & A & AA \\
\hline Slovakia & A & AA \\
\hline Japan & A & A \\
\hline Spain & BBB & \\
\hline
\end{tabular}

All countries in Table 12 are investment-grade and CDSs suggest an upgrade of their credit ratings.

Table 13 - Countries with Slightly Higher Median Rating than Implied Rating (compiled by the authors)

\begin{tabular}{|c|c|c|}
\hline Country & Median Rating & Implied Rating \\
\hline Netherlands & AAA & AA \\
\hline Abu Dhabi & AA & A \\
\hline Qatar & AA & BBB \\
\hline Poland & A & BBB \\
\hline Peru & A & BBB \\
\hline Malaysia & A & BBB \\
\hline Slovenia & A & \\
\hline
\end{tabular}

Table 14 - Countries with Substantially Higher Median Rating than Implied Rating (compiled by the authors)

\begin{tabular}{|c|c|c|}
\hline Country & Median Rating & Implied Rating \\
\hline Singapore & AAA & A \\
\hline Chile & AA & BBB \\
\hline China & AA & BBB \\
\hline South Africa & BBB & S \\
\hline
\end{tabular}

All countries in Table 13 and Table 14 are investment-grade and CDSs suggest a downgrade of their credit rating. Substantial potential downgrades for countries in Table 14 mean that Singapore, Chile, and China would drop by two categories and South Africa would even obtain a speculative-grade rating,

We can now investigate the accuracy of ratings delivered by rating agencies in case they differ, or if at least one of the ratings (Moody's, S\&P, or Fitch) coincides with its respective implied rating.

First, we notice that out of 18 countries with different median and implied ratings, there are only four countries (Table 15) where at least one of the ratings provided by rating agencies coincides with the implied rating. Such coincidence is marked with a plus symbol. Differences are marked with a minus symbol. S\&P is the most precise rating agency in his respect, although this example of only four countries is quite small. 
П. Будінській, М. Безвода. Інноваційний підхід до управління кредитним ризиком

Table 15 - Countries with Different Median Rating and Implied Rating (compiled by the authors)

\begin{tabular}{|c|c|c|c|c|c|}
\hline Country & Median Rating & Implied Rating & Moody's & S\&P & Fitch \\
\hline Netherlands & AAA & AA & - & + & - \\
\hline Czech Republic & A & AA & - & + & - \\
\hline Poland & A & BBB & - & + & - \\
\hline Slovenia & A & BBB & + & - & - \\
\hline
\end{tabular}

The same procedure will now be applied to the other 34 countries with the same median and implied ratings.

Table 16 - Countries with Equal Median Rating and Implied Rating (compiled by the authors)

\begin{tabular}{|c|c|c|c|c|c|}
\hline Country & Median Rating & Implied Rating & Moody's & S\&P & Fitch \\
\hline United States & AAA & AAA & + & - & + \\
\hline Estonia & A & A & + & - & + \\
\hline Mexico & BBB & BBB & - & + & + \\
\hline Hungary & BBB & BBB & + & - & + \\
\hline Bulgaria & BBB & BBB & + & - & + \\
\hline Russia & S & S & + & + & - \\
\hline Turkey & S & S & + & + & - \\
\hline Indonesia & BBB & BBB & + & - & + \\
\hline
\end{tabular}

Moody's, S\&P, and Fitch deliver different ratings for only eight of these 34 countries. Moody's is the most precise rating agency for this group. Note that each of the last five countries in Table 16 (Hungary, Bulgaria, Russia, Indonesia, and Turkey) have at least one investment-grade rating and at least one speculative-grade rating. For these five countries, the match with the credit rating provided by Moody's and the implied rating is $100 \%$.

Conclusion and directions of further research. Implied rating based on CPD that is derived from CDS spreads is a powerful tool used to verify the sovereign ratings granted by rating agencies. Implied ratings are defined by CPD intervals (Table 6).

First, implied rating could provide a signal for future upgrades or downgrades of ratings in cases where the median rating and implied rating differ. Special attention should be paid to cases where all three ratings are investment-grade, but the implied rating category is $S$ (South Africa), or, if some ratings are investmentgrade and others are speculative-grade (Hungary, Bulgaria, Russia, Indonesia, and Turkey).

Second, we can find which rating agency is the most precise by using implied ratings. In cases where implied rating and median rating are the same, but the ratings from Moody's, S\&P, and Fitch are different, we can use implied rating to verify the relevant rating agency when its credit rating and implied rating are the same. In case implied rating and median rating are different, one rating agency can still provide a rating that is equal to the implied rating.

This research was based on data to 31 January 2017. The next step would be to calculate CPD intervals for different dates and to investigate whether they are stable. Another direction of research is to analyze past CDS spreads to find whether implied rating signaled changes in credit ratings. This paper deals only with sovereign ratings. The model can be used for corporate ratings as well. It could also be of interest to investigate implied ratings based on bond yields.

1. Berg, T., \& Streitz, D. (2016). Determinants of the size of the sovereign credit default swap market. The Journal Of Fixed Income, 25 (3), 58-73.

2. Budinský, P., Heissler, H., \& Wawrosz, P. (2013). Relationship between bond spreads and CDS spreads. Scientia Et Societas, 9(4), 52-64.

3. Budinský, P. (2014). Relationship between sovereign ratings and CDS prices. In Controlling and Knowledge. Wroclaw: Publishing House of Wroclaw University of Economics.

4. Budinský, P., \& Bezvoda, M. (2016). CDS and bond sreads as two measures of credit risk. Actual Problems In Economics, 
(186), 280-290.

5. Callen, J. L., Livnat, J., \& Segal, D. (2009). The impact ofeEarnings on the pricing of credit default swaps. The Accounting Review, 84(5), 1363-1394.

6. Castellano, R., \& D'Ecclesia, R. L. (2013). CDS volatility: the key signal of credit quality. Annals Of Operations Research, 205(1), 89-107.

7. Cizel, J. (2013). Are credit rating announcements contagious? Evidence on the transmission of information across industries in credit default swap markets. The Journal Of Fixed Income, 23(2), 27-60.

8. de Haan, J., \& Amtenbrink, F. (2011). Credit rating agencies. DNB Working Paper, 278. DOI: http://dx.doi.org/10.2139/ssrn.1950563.

9. Drago, D., \& Gallo, R. (2016). The impact and the spillover effect of a sovereign rating announcement on the euro area CDS market. Journal Of International Money And Finance, 67(October), 264-286.

10. Georgievska, A. (2008). Sovereign rescheduling probabilities in emerging markets: a comparison with credit rating agencies' ratings. Journal Of Applied Statistics, 35(9), 1031-1051.

11. Iyengar, S. (2010). Are sovereign credit ratings objective and transparent?. lup Journal Of Financial Economics, 8(3), 7-22.

12. lyengar, S. (2012). The credit rating agencies-Are they reliable? A study of sovereign ratings. Vikalpa, 37(1), 69-82.

13. Kiesel, F. (2015). Regulation of uncovered sovereign credit default swaps - evidence from the European Union. The Journal Of Risk Finance, 16(4), 425-443.

14. Site of Moody's. moodys.com. Retrived from https://www.moodys.com.

15. Site of Standard and Poor's (S\&P). standardandpoors.com. Retrived from https://www.standardandpoors.com/

16. Site of Fitch. fitchratings.com. Retrived from https://www. fitchratings.com/site/home.

17. Site of Deutsche Bank Research. research.db.com. Retrived from https://research.db.com/Research/Register.

П. Будінській, $\mathrm{PhD}$, доцент кафедри фінансів, факультет економічних досліджень, Університет фінансів та управління (м. Прага, Чехія);

M. Безвода, Ing, кафедра фінансів, факультет економічних досліджень, Університет фінансів та управління (м. Прага, Чехія) Інноваційний підхід до управління кредитним ризиком

Кредитний рейтинг - це традиційний вимір кредитного ризику на фрінансових ринках. Цей документ представляє інноваційний підхід, що базується на припущених рейтингах, визначених спредами CDS. Використовуючи цей підхід, кредитним ризиком можна краще управляти, оскільки CDS надаються щодня. Неявний рейтина порівнюється 3 кредитними рейтингами, наданими Moody's, S \& P та Fitch. Модель неявного рейтингу стосується лише суверенних рейтингів. Для порівняння обох типів зазначених рейтингів було обрано 52 країни. Модель використовує кумулятивну імовірність дефролту (CPD), отриману від спредів CDS, а основними результатами є інтервали CPD, які визначають передбачувані кредитні рейтинги. Для тих країн, де рейтинг кредитів та імовірний кредитний рейтина відрізняються, цей документ показує, наскільки передбачуваний рейтинг може слугувати сигналом для потенційного оновлення або зниження кредитного рейтингу, наданого рейтинговими агентствами. Представлена модель також використовується для перевірки рейтингів, наданих Moody's, S\&P ma Fitch у випадках, коли ці агентства надають різні рейтинги для певної країни. Це особливо важливо, коли деякі рейтинги є інвестиційними, а інші - спекулятивними.

Ключові слова: кредитний рейтинг, управління кредитним ризиком, рейтингове агентство, кредитний десролтний своп (CDS), сукупна ймовірність дефолту (CPD).

П. Будинский, $\mathrm{PhD}$, доцент кафедры финансов, факультет экономических исследований, Университет финансов и управления (г. Прага, Чехия);

M. Безвода, Ing, кафедра финансов, факультет экономических исследований, Университет финансов и управления (г. Прага, Чехия)

Инновационный подход к управлению кредитным риском

Кредитный рейтине - это традиционное измерение кредитного риска на финансовых рынках. Этот документ представляет инновационный подход, основанный на допущенных рейтингах, определенных спредами CDS. Используя этот подход, кредитным риском можно лучше управлять, поскольку CDS предоставляются ежедневно. Неявный рейтинг сравнивается с кредитными рейтингами, предоставленными Moody's, $S$ \& $P$ и Fitch. Модель неявного рейтинге касается только суверенных рейтингов. Для сравнения обоих типов указанных рейтингов были выбраны 52 страны. Модель использует кумулятивную вероятность десолта (CPD), полученную от спредов CDS, а основными результатами являются интерваль CPD, которые определяют предполагаемые кредитные рейтинги. Для тех стран, где рейтинг кредитов и вероятный кредитный рейтинг отличаются, эта статья показьвает, насколько предполагаемый рейтинг может служить сигналом для потенциального обновление или снижение кредитного рейтинга, предоставленного рейтинговыми агентствами. Представленная модель также используется для проверки рейтингов, предоставленных Moody's, S\&P и Fitch в случаях, когда эти агентства предоставляют различные рейтинги для определенной страны. Это особенно важно, когда некоторые рейтинги являются инвестиционными, а другие - спекулятивными.

Ключевые слова: кредитный рейтинг, управление кредитным риском, рейтинговое агентство, кредитный дефолтный своп (CDS), совокупная вероятность дефолта (CPD).

Отримано 30.06 .2017 p. 